\title{
Peran Ustadz dalam Membimbing Mental Santri Membentuk Kepribadian Islam di Pondok Pesantren an-Najah Kudus
}

\author{
Ahmad Ainun Najib \\ Universitas Islam Negeri (UIN) Sunan Kalijaga \\ Ahmadnajib186@gmail.com
}

\begin{abstract}
This study aims to determine the implementation of ustadz's mental guidance to students, to know the personality of Islamic students, to know the role of Ustadz in guiding students' mentality to shape Islamic personality. The ustadz has a very important role in guiding santri to become Islamic. The method used is qualitative. Data collection uses interviews, observation, documentation. The research informants were religious teacher and students. The results showed that the guidance of the Islamic teacher to students was held every week precisely on Monday after 19.15, Islamic Personality of students at An-Najah Islamic Boarding School Tanjungrejo Jekulo Kudus was very good, it was seen from students always following positive activities in their daily lives. The role of the Ustadz in guiding mentally Shaping the Islamic personality of the santri in An-Najah Tanjungrejo Islamic Boarding School Jacuro Kudus is done well, which is to provide encouragement and guidance so that students can apply the mau'idzha hasanah material in their daily lives.
\end{abstract}

Keywords: The role of ustadz, guiding, Islamic personality

\begin{abstract}
Abstrak
Penelitian ini bertujuan untuk mengetahui pelaksanaan bimbingan mental Ustadz terhadap santri, mengetahui kepribadian Islam santri, mengetahui peran Ustadz dalam membimbing mental santri membentuk kepribadian Islam. Ustadz memiliki peran yang sangat penting dalam membimbing santri agar berkperibadian Islami. Metode yang digunakan adalah kualitatif. Pengumpulan data menggunakan wawancara, observasi, dokumentasi. Informan penelitiannya adalah ustaz dan santri. Hasil penelitian menunjukkan bahwa bimbingan ustaz terhadap santri dilaksanakan setiap minggu sekali tepatnya pada hari senin setelah jam 19.15, Kepribadian Islam
\end{abstract}


santri di Pondok Pesantren An-Najah Tanjungrejo Jekulo Kudus adalah sangat baik, ini terlihat dari santri selalu mengikuti aktivitas positif dalam kehidupan keseharianya. Peran Ustadz dalam membimbing mental Membentuk kepribadian Islam santri di Pondok Pesantren An-Najah Tanjungrejo Jekulo Kudus dilakukan dengan baik, yaitu memberi dorongan dan bimbingan agar santri dapat mengaplikasikan materi mau'idz̧ ha hasahah dalam kehidupannya sehari-hari.

Kata Kunci: Peran ustadz, membimbing, kepribadian Islam

\section{Pendahuluan}

Kiai dan Ustadz merupakaan komponen penting yang amat menentukan keberhasilan pendidikan pesantren. Selain itu tidak jarang seorang Kiai atau Ustazd adalah pendiri dan pemilik pesantren itu atau keluarga itu atau keluarga keturunannya. Dengan demikian pertumbuhan dan perkembangan suatu pesantren amat bergantung pada figur Kiai atau Ustadz tadi. Sehingga pertimbangan utama seorang santri yang akan memasuki suatu pesantren adalah berdasar pada kebesaran dan kemasyhuran nama yang di sanding yang di sanding oleh Kiai dan Ustadz nya itu. ${ }^{1}$

Bimbingan merupakan proses pemberian bantuan terhadap individu agar dalam kehidupan keagamaanya seantiasa selaras dengan ketentuan dan petunjuk Allah sehingga dapat mencapai kebahagian hidup dunia dan akhirat. ${ }^{2}$, Sesuai dengan hakikatya manusia memerlukan pula pemenuhan kebutuhan rohani dalam arti psikologi. Seperti telah diketahui, manusia dianugerahi kemampuan rohaniah (psikologis) pendengaran, pengelihatan dan kalbu dalam bahasa seharihari dengan kemampuan cipta rasa dan karsa

Pada zaman era 4.0 tidak bisa dipungkirilagi anak-anak khusunya remaja kurangnya akhlak serta kepribadian yang menyimpang dari agama maupun sosial semakin meningkat Kapolda Metro Jaya Irjen Putut Bayu Ajiseno mengatakan bahwa terjadi peningkatan kenakalan remaja sebanyak 11 kasus atau 36.66\% di tahun 2012, Total kasus kenakalan remaja yang terjadi selama 2012 mencapai 41 kasus, sementara pada tahun 2011 hanya 30 kasus dan akan terus meningkat (http://news.detik.com). Situs Badan Kependudukan dan Keluarga Berencana Nasional (BKKBN) memberitakan bahwa dari 2.4 juta kasus aborsi, 700.000 hingga 800.000 pelakunya adalah remaja. ${ }^{3}$

${ }^{1}$ Tim penyusun Diektorat Jendral Kelembagaan Agama Islam, Pola Pembelajaran Dipesantren, Departeman Agama RI, Jakarta, 2003, hlm.15-16.

${ }^{2}$ Dewa Ketut Skardi, Proses Bimbingan Dan Penyuluhan, Ineka cipta, jakarta, 1998, hlm.5.

${ }^{3}$ Faktor-faktor Penyebab Kenakalan Remaja di Desa Kemadang Kecamatan Tanjungsari Kabupaten GunungkidulSiti Fatimah dan M Towil Umuri,urnal Citizenship, Vol. 4 No. 1, Juli 2014. 
Pada sistem pendidikan pesantren sebuah peantren yang dikelolah oleh seorang Kiai saja dan di bantu dengan oleh beberapa orang Ustadz dan terkadang dikelolah oleh beberapa Kiai yang masih dalam satu keluaraga besar dengan dipimpin oleh kiai sepuh. Fungsi para Ustadz, ini adalah sebagai pelajar kepada para santri tingkat dasar dan menengah di bawa bimbingan dan petunjuk Kiai. Proses pergantian kepemimpinan di pesantren itu sendiri pada umumnya menganut sisitem pergantian secara geologis. ${ }^{4}$

Dengan adanya pengajaran serta bimbingan dari Kiai atau Ustadz maka akan memberikan dampak tersendiri bagi kepribadian santri, sebab Kiai atau Ustadz dalam kehidupan sehari-hari di lingkungan pondok memberikan contoh yang baik bagi santrinya, Sebagaimana yang ada di Pondok An-Najah Desa Tanjungrejo Kecamatan Jekulo Kabupaten Kudus terdapat bimbingan atau arahan dari para Ustadz atas saran dari Kiai atau pengasuh pondok kepada santrinya dengan tujuaan untuk melatih mental para santri-santri yang umumnya dalam usia remaja, Sebab tumbuh dan berkembangnya manusia dipengaruhi oleh pengalaman belajar sepanjang hidupnya. Perkembanganya berlangsung secara terus menerus sejak masa konsepsi sampai masa tua. ${ }^{5}$

\section{Bimbingan Mental}

Terdapat dua kata terkait dengan adanya pengertian bimbingan mental, yaitu bimbingan dan mental. Menurut Prayetno dan Erman, bimbingan adalah proses pemberian bantuan yang dilakukan oleh ahli kepada orang yang dibimbing agar memiliki kemampuan secara mandiri. ${ }^{6}$ Jadi, bimbingan merupakan pemberian bantuan yang dilakukan oleh para ahli dalam bidangnya kepada klien sebagai orang yang menerima penerimaan bantuan

Merurut Bimo Waligito sebagaimana yang dikutip oleh Farida dan Saliyo mengatakan bimbingan adalah bantuan atau pertolongan yang diberikan kepeda individu atau sekumpulan individu dalam menghindari atau mengatasi kesulitankesulitan di dalam mencapai kesejahteraan hidupnya. ${ }^{7}$ Jadi bmbingan merupakan pertolongan yang diberikan kepada individu untuk mencapai kesejahteraan dalam menjalani kehidupanya.

Sedangkan mental merupakan pengalaman yang diaktifkan oleh perangsang internal maupun bermacam-macam keadaan jasmani. ${ }^{8}$ Perkembangan mental ke arah berfikir logis juga mempengaruhi pandangan dan

${ }^{4}$ Tim penyusun Diektorat Jendral Kelembagaan Agama Islam, Op, cit., hlm. 16.

${ }^{5}$ Studi awal di Pondok Pesantren An-Naja Kudus hlm. 92 .

${ }^{6}$ Prayitno dan Erman Amti, Dasar-Dasar Bimbingan Konseling, Rineka Cipta, Jakarta.1994, hlm. 12 .

${ }^{7}$ Farida dan Saliyo, teknik, layanan bimbingan Konseling Islam, STAIN kudus, Kudus, 2008,

${ }^{8}$ Soeparwoto, dkk, Psikologi Perkembangan, UPT MKK UNNES Press, Semarang, 2003, hlm. 73 . 
kepercayaannya kepada Tuhan. Karena meraka (santri) tidak dapat melupakan Tuhan dari segala persitiwa yang telah terjadi di alam ini. ${ }^{9}$

Berdasaran pengertian diatas, dapat dipahami bahwa bimbingan mental dapat diartikan sebagai suatu proses pemberian bantuan kepada individu yang diakukan secara keseimbangan supaya individu tersebut dapat memahami dirinya sendiri. Dia sangup mengarahkan dirinya dan dapat bertindak secara wajar sesuai dengan tuntunan dan keadaan lingkungan sekolah, keluarga dan masyarakat dan kehidupan pada umumnya dan nantinya memiliki mental yang baik.

Suatu proses bimbingan antara seorang pembimbing dan seorang klien, terdapat dua bentuk bimbingan, yaitu: ${ }^{10}$

1. Layanan bimbingan individual merupakan layanan bimbingan yang memungkinkan klien mendapatkan layanan langsung secara tepat muka, perorangan dengan seorang pembimbing dalam rangka pembahasan dan mengatasi masalah pribadi yang diderita klien. Pembimbing dalam hal ini melakukan komunikasi langsung secara individual dengan pihak yang dibimbingnya. Hal ini dapat dilakukan dengan mempergunakan teknik percakapan pribadi, yakni pembimbing melakukan dialog langsung tatap muka dengan pihak yang di bimbing, kunjungan rumah (Home visit), yakni pembimbing mengadakan dialog dengan kliennya tetapi dilaksanakan di rumah klien sekaligus mengamati keadaan klien dan lingkungannya.

2. Layanan bimbingan kelompok merupakan layanan bimbingan yang dilakukan secara bersama-sama melalui dinamika kelompok. Pembimbing melakukan komunikasi langsung dengan klien dalam kelompok. Hal ini dapat dilakukan dengan teknik diskusi kelompok, yakni pembimbing melaksanakan dengan cara mengadakan diskusi bersama kelompok klien yang mempunyai masalah yang sama.

Selain dua bentuk layanan bimbingan di atas, secara Islam terdapat beberapa bentuk bimbingan dakwah, yaitu: ${ }^{11}$

1. Dakwah bil lisan yakni metode dakwah lewat lisan misalnya khutbah jumat atau ceramah-ceramah agama di acara-acara pengajian

2. Dakwah bil Qolam yakni metode dakwah melalui tulisan misalnya pada waktu sore hari anak kecil di masjid mengaji Al-Qur'an

3. Dakwah bil nikah yakni metode dakwah melalui pernikahan seperti orang yang hijah tadi menikahi penduduk desa agar mereka mempunyai keturunan dan bisa meneruskan dakwah islam di masyarakat.

\footnotetext{
'Zakiyah Daradjat, Ilmu Jiwa Agama, Bulan Bintang, Jakarta, 1970, hml.74.

${ }^{10}$ Prayitno dan Erman Amti, Dasar-dasar Bimbingan dan Konseling, Jakarta: Rineka Cipta, 1998), hlm. 178

${ }^{11}$ Abdullah, "Metode Dakwah Islam" Artikel, diambil melalui http:/dakwahislam.org/macam-macam-metode-dakwah.html, diakses tanggal 30 desember 2016.
} 
Prinsip adalah dasar atau landasan praktis yang harus di ikuti dalam pelaksanaan bimbingan. Adapun prinsip-prinsip dasar bimbingan yaitu:

1. Bimbingan berdasarkan atas penyandraan akan kemudian dan nilai batinia seseorang.

2. Bimbingan memikul tanggung jawab yang sama beratnya, baik terhadap perseorangan maupun terhadap masyarakat.

3. Bimbingan berorientasi koopratif bukan memberi kewajiban. Oleh sebab itu bimbingan bersifat monitorial dan tidak memberi tempat bagi paksaaan.

4. Bimbingan hendaknya dibebankan kepada meraka yang memiliki panggilan secara alamiah terhadap tugas itu dan memiliki latar belakang pendidikan serta pengalaman yang diperlukan. ${ }^{12}$ Dengan adanya pengalaman dan latar belakang dari pembimbing yang baik, dapat memberikan inovasi bagi klien untuk terus mengikuti arahannya dalam kehidupan sehari-hari.

Prinsip-prinsip yang bersifat umum, yaitu:

1. Bimbingan itu berhubungan dengan sikap dan tingkah laku individu, perlunya diingat bahwa sikap dan tingkah laku itu diberikan dari segala aspek kepribadiaan yang unik.

2. Perlu dikenal dan dipahami perbedaan individual daripada individu-individu yang akan dibimbing ialah akan memberikan bimbingan yang tepat sesuai dengan apa yang dibutuhkan oleh individu yang dibimbing.

3. Bimbingan adalah proses membantu individu untuk dapat membantu dirinya sendiri dalam memecahkan masalah yang dihadapinya.

4. Bimbingan hendaknya berpusat pada diri individu yang mendapatkan bimbingan.

5. Bimbingan harus di mulai dengan proses indentifikasi kebutuhankebutuhan yang dirasakan oleh individu yang kan dibimbing.

6. Bimbingan harus bersifat fleksibel sesuai dengan kebutuhan individu dan masyarakat.

7. Pelaksanaan program bimbingan harus dipimpin oleh seorang yang memiliki keahlian dalam bidang bimbingan dan sanggup berkerja sama dengan para pembantunya. ${ }^{13}$

Menurut Abdul Mujib, Menjelaskan bahwa kepribadiaan islam merupakan studi islam yang berhubungan dengan tingkah laku manusia dalam realisinya dangan alam, sesamanya, dan kepada sang khaliknya agar dapat meningkatkan kualitas hidup di dunia dan akhirat. ${ }^{14}$ Kepribadian islam memliliki arti serangkaian perilaku normatif manusia, baik sebagai makhluk individu

${ }^{12}$ Farida dan Saliyo, Op. Cit., hlm.52.

${ }^{13} \mathrm{Ibid}$, hlm 52-53

${ }^{14}$ Abdul Mujib, Kepribadian Dalam Psikologi Islam, Raja Grafindo Persada, Jakarta, 2006, hlm. 33-34. 
maupun makhluk sosial, yang normanya diturunkan dari ajran islam, yang bersumber dari Al-Qur'an dan As-Sunnah. ${ }^{15}$

Memahami pengertian di atas, maka pendapat aspek kepribadiaan secara islam dapat dilihat dari strukur kepribadian islam. Menurut Al-Zakari sebagaimna yag dikutip oleh Abdul Mujib, bahwa studi tentang diri manusia dapat dilihat melalui 3 sudut, yaitu :

1. Jasad (fisik); apa dan bagaimana oragnisme dan sifa-sifat uniknya

2. Jiwa (psikis); apa dan bagaimana hakikat dan sifat-sifat uniknya

3. Jasad dan jiwa (psikofisik); berupa akhlak, perbuatan dan gerakan. ${ }^{16}$

Ketiga kondisi tersebut terminologi Islam lebih dikenal dengan term aljasad, al-rub,dan al-nafs. Jasad merupakan aspek biologis atau fisik manusia, ruh merupakan aspek psikologis atau psikis manusia dan nafs merupakaan aspek psikofisik manusia yang merupakan sinergi antara jasad dan ruh. Jasad tanpa ruh merupakan subtansi yang mati, sedang ruh tanpa jasad tidak dapat teraktualisasi. Oleh sebab itu, perlu adanya sinergi antara kedua aspek tersebut agar masingmasing keinginan jasad dan ruh dalam diri manusia dapat terpenuhi. Frman Allah :

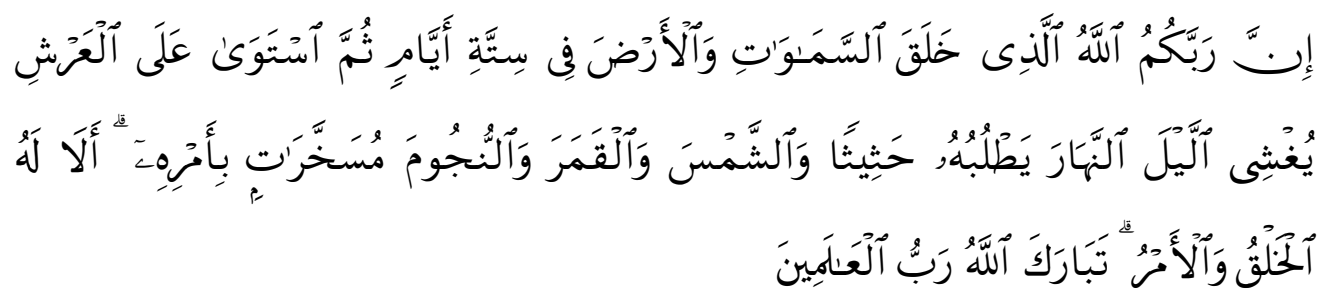

Sesunggubnya Tuhan kamu ialah Allah yang telah menciptakan langit dan bumi dalam enam masa, lalu Dia bersemayam di atas 'Arsy[548]. Dia menutupkan malam kepada siang yang mengikutinya dengan cepat, dan (diciptakan-Nya pula) matahari, bulan dan bintang-bintang (masing-masing) tunduk kepada perintah-Nya. Ingatlah, menciptakan dan memerintah hanyalah hak Allah. Maha suci Allah, Tuban semesta alam. ( Qs.AlA'raf:54) ${ }^{17}$

Kepribadian Islam adalah suatu kepribadian yang terbentuk dari aspek intelektual Islam dan spiritual Islam. ${ }^{18}$ Intelektual islam adalah aktifitas berfikir, menganalisis dan memutuskan sesuatu berdasarkan landasan Islam, serta

${ }^{15}$ Ibid, hlm.14.

${ }^{16} \mathrm{Ibid}$, hlm. 56.

${ }^{17} \mathrm{Al}-\mathrm{Qur}$ 'an Surat Al-A'raf ayat 54, yayasan penyelangaraan penerjemahan dan penafsiran Al-Qur'an, Al-Qur'an dan Terjemahannya, Depag RI, Jakarta, 1991,hlm. 159.

${ }^{18}$ Fathi Yakan,Seri Madah Tarbiayah Memotret Wajah Dakwah, Memetakan Problem Dan Menawarkan Solusi, PT Era Aicitra Intermedia, Solo, 2010, hlm.165-166. 
bedasarkan landasan teori yang integral dan komperhensif tentang alam raya, manusia dan kehidupan. ${ }^{19}$

Penelitian ini mengunakan pendekatan kualitatif. Peneliti mendapatkan data secara langsuang dari subyek peneliti yaitu mengenai peran Ustadz membimbing mental membentuk kepribadian Islam santri di Pondok Pesantren. Dan data dalam penelitian bersumber dari: pertama, hasil observasi; kedua, wawancara (Interview) dengan ustadz, santri ; ketiga, dokumentasi terkait data yang ada dilingkungan pondok pesantren An-najah.

\section{Hasil dan Pembahasan}

\section{Pondok Pesantren an-Najah Tanjungrejo Jekulo Kudus}

Pondok Pesantren An-Najah beralamat di Patihan Tanjungrejo Jekulo Kudus. Embrio dari pesantren kecil ini adalah adanya kajian ilmu-ilmu agamaIslam di Kauman Ngembalrejo mulai tahun 2000 sampai tahun 2003. Waktu itu, pendiri sekaligus pengasuh pesantren ini, K.H. Edi Bachtiar, M. Ag memang belum mempunyai tempat untuk berteduh secara nyaman, masih kontrak di daerah Ngembalrejo Bae Kudus (belakang PR. Jambu Bol). Kajian ini diikuti oleh remaja-remaja warga sekitar. Waktu kajian yaitu mulai ba'da maghrib sampai pukul 21.00 WIB.Setelah menempati rumah di Jekulo, pertengahan tahun 2003, barulah pesantren ini diresmikan oleh KH. Ahmad Basyir, senior sekaligus ulama di Jekulo Kudus yang namanya sudah membumi di lingkungan pesantren se-Indonesia. Beliau juga yang memberikan nama untuk pesantren ini. ${ }^{20}$ Untuk lebih jelas struktur kepengurusan Pondok Pesantren An-Najah Kudus dapat dilihat struktur sebagai berikut :

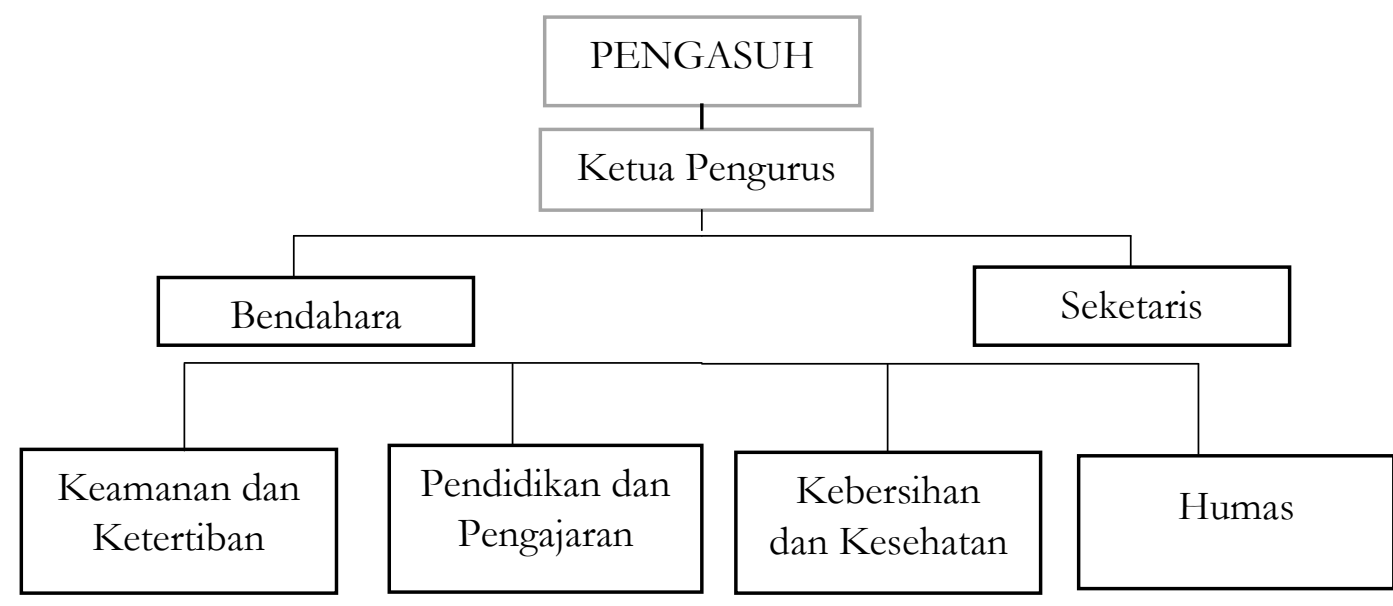

${ }^{19}$ Ibid hlm 167.

${ }^{20}$ Wawancara dengan K.H Edi Bachtiar selaku pengasuh Pondok An-Najah di Pondok Pesantren An-Najah di desa tanjungrejo Kecamatan jekulo kabupaten kudustanggal 20-11-2019 Pukul 09:00 


\section{Kegiatan Pembelajaran di Pondok Pesantren An-Najah}

Belajar dan mengaji merupakan kegiatan pokok di pesantren ini keduanya tercakup dalam program pendidikan terpadu yang saling berkaitan yaitu:

1. Belajar

Belajar secara umum, berlangsung melalaui para Ustadz dan dibimbing agar santri belajar dengan baik dan benar sesuai dengan target yang di inginkan para Ustadz adapun pelajaran yang diberikan antara lain Akidah Akhlak, Tauhid Tasawuf, Fiqih, Nahwu, Shorof, Hadits, dan Tafsir

2. Mengaji

Mengaji yang dimaksud adalah mengaji Al-Qur'an, yang di berikan bagi setiap semua santri dengan ketentuan 2 kali dalam sehari semalam. Namun bagi santri yang menghafal Al-Qur;an ada ketentuan Khusus yaitu 3 sampai 4 dalam sehari semalam.

Upaya membentuk akhlak santri Pondok Pesantren An-Najah diwujudkan dalam berbagai kegiatan. Dalam upaya menanamkan cinta kepada Allah dan Agar santri memiliki akhlak yang baik, maka di pesantren diterakpan Khotmil Qur'an setiap malam selasa dan pembacaan kitab kuning yang di ajarkan oleh para Kiai atau Ustadz. Hal ini lebih diorientasikan pada pembelajaraan agama yang nantinya akan dapat mempengaruhi kepribadian santri serta menimbulkan kecintaan kepada Allah. ${ }^{21}$

\section{Metode bimbingan mental}

Kegiatan bimbingan mental pada santri di Pondok Pesantren An-Najah Desa Tanjungrejo Kecamatan Jekulo Kabupaten Kudus dilaksanakan setiap hari jum'at atau seminggu sekali dan setiap hari tepatnya habis shalat subuh yang bertempat di masjid Baitur Rahman",22

Kegiatan bimbingan mental yang di lakukan para Ustadz di Pondok Pesantren An-Najah Desa Tanjungrejo Kecamatan Jekulo Kabupaten Kudus Mau'idz̧a Hasanah. Sebagaimana data yang peneliti di peroleh bahwa bimbingan mental yang dilakukan oleh Para Ustadz di Pondok Pesantren An-Najah Desa Tanjungrejo Kecamatan Jekulo Kabupaten Kudus adalah sebagai berikut:

1. Tadarus Al-Qu'an atau Khotmil Qur'an

a. Mempelancar dalam Membaca Al-Qur'an

${ }^{21}$ Wawancara dengan K.H Edi Bachtiar selaku pengasuh Pondok An-Najah di Pondok Pesantren An-Najah di desa tanjungrejo Kecamatan jekulo kabupaten kudustanggal 21-11-2019 Pukul 09:00

${ }^{22}$ Wawancara dengan Ahmad Syukron Ustadz di Pondok Pesantren An-Najah di desa tanjungrejo Kecamatan jekulo kabupaten kudustanggal 20-11-2019 Pukul 20:00 
b. Kesatuan diantara para anggota untuk lebih memperhatikan temantemanya

c. Mengutamakan kepentingan umum dari pada kepentingan sendiri

d. Mau'id ₹ৃha Hasanah (Dialog Keagamaan)

e. Ceramah

f. Tanya Jawab

g. Diskusi ${ }^{23}$

2. Memberikan Bimbingan

Berdasarkan data lapangan yang ada bahwa bentuk bimbingan mental yang diselenggarakan oleh para Ustadz terhadap santri di Pondok Pesantren AnNajah Desa Tanjungrejo Kecamatan Jekulo Kabupaten Kudus ada dua macam, yaitu: Pertama, Bimbingan secara individual, contohnya : melalaui pemberian arahan secara pribadi di ruang khusus. Kedua, bimbingan secara kelompok, contohnya : melalui pengajian bersama-sama.

Bimbingan secara individual dilakukan setiap hari senin pada pukul 19:15 setelah sholat Isya sampai selesai di Masjid sendiri sedangkan materi yang disampaikan adalah:

a. Akhlak. Dalam hal ini para Ustadz memberikan arahan pada santri tentang akhlak dalam kehidupan sehari-hari, seperti membuang sampah pada tempatnya, disiplin dalam shalat berjama'ah dan lain sebaginya.

b. Moral. Dalam hal ini para Ustadz memberikan arahan pada santri mentaati perintah guru, mentaati perintah orang tua, hidup rukun, guyup, kompak dengan santri dan lain sebagainya.

c. Etika. Dalam hal ini para Ustadz memberikan arahan pada santri tentang akhlak dalam kehidupan sehari-hari, seperti membuang sampah pada tempatnya, disiplin dalam shalat berjama'ah dan lain sebagainya untuk disiplin dalam mengaji, baik belajar kitab kuning atau mengikuti kegiatankegiatan keagamaan dengan baik dan sopan. ${ }^{24}$

Sedangkan bimbingan secara kelompok dilakukan setiap hari setelah shalat subuh sampai selesai di masjid baitur rahman sedangkan materi yang disampaikannya adalah:

a. Melaksanakan segala kegiatan dengan niat ibadah

b. Berakhlakul karimah (guyub, rukun, kompak)

c. Jangan sengaja berbuat kesalahan atau melangar aturan. Kalau terlanjur melanggar segeralah bertaubat.

\footnotetext{
${ }^{23}$ Wawancara dengan Syamsul Munif di Pondok Pesantren An-Najah di desa tanjungrejo Kecamatan jekulo kabupaten kudustanggal 23-11-2019 Pukul 14:00

${ }^{24}$ Wawancara dengan Ahmad Syukron Ustadz di Pondok Pesantren An-Najah di desa tanjungrejo Kecamatan jekulo kabupaten kudustanggal 20-11-2019 Pukul 11:00
} 
d. Melaksanakan 3 D (Tiga disiplin), yaitu: disiplin waktu, disiplin ibadah, disiplin belajar/mengajar

e. Melaksanakan kegiatan dengan pedoman hati dan beramal lahir (ringan sejuk, beres, tidak terpaksa, sabar,teliti dan hati-hati) dengan arahan 1) Sejuk lahir hati tenang tidak panas 2) sabar biar bisa bersama Allah menuruti perintah Allah 3) teliti biar tidak salah dalam melakukan perkara 4) hati-hati biar selamat 5) mengamalkan amalan Rasullullah (ngapes, ngasor, ngagungke liyan) dengan tafsir, Ngapes, berlaku Merasa dirinya yang kuat hanya Allah. Ngalah, berlaku mengalah yang menang hanya Allah, ngegongke liyan, berlaku mengagungkan pihak lain dengan dasar tawadlu, sopan, santun dengan landasan peran senior akhlakul karimah. ${ }^{25}$

Untuk mengetahui lebih jelasnya dari keterangan di atas maka dapat dipahami pada tabel di bawa ini:

Tabel 1

\section{Bentuk bimbingan}

\begin{tabular}{|c|c|c|c|c|c|}
\hline \multirow[b]{2}{*}{ No } & \multirow{2}{*}{$\begin{array}{c}\text { Bentuk } \\
\text { Bimbingan }\end{array}$} & \multirow{2}{*}{$\begin{array}{c}\text { Metode } \\
\text { yang } \\
\text { Digunakan }\end{array}$} & \multirow{2}{*}{$\begin{array}{c}\text { Teknik } \\
\text { Bimbingan } \\
\text { Mental }\end{array}$} & \multicolumn{2}{|c|}{ Contoh } \\
\hline & & & & $\begin{array}{c}\text { Sebelum } \\
\text { Bimbingan } \\
\text { Mental }\end{array}$ & $\begin{array}{c}\text { Sesudah } \\
\text { Bimbingan } \\
\text { Mental }\end{array}$ \\
\hline 1 & $\begin{array}{l}\text { Bimbingan } \\
\text { secara } \\
\text { individual }\end{array}$ & $\begin{array}{l}\text { Metode } \\
\text { ceramah }\end{array}$ & $\begin{array}{l}\text { Diberikan } \\
\text { arahan } \\
\text { secara } \\
\text { pribadi di } \\
\text { ruang } \\
\text { khusus }\end{array}$ & $\begin{array}{c}\text { Suka } \\
\text { menggangu } \\
\text { temanya }\end{array}$ & $\begin{array}{c}\text { Merasa } \\
\text { sungkan atau } \\
\text { malu untuk } \\
\text { menggangu } \\
\text { temanya pada } \\
\text { saat mengaji }\end{array}$ \\
\hline 2 & $\begin{array}{l}\text { Bimbingan } \\
\text { secara } \\
\text { kelompok }\end{array}$ & $\begin{array}{c}\text { Metode } \\
\text { ceramah } \\
\text { dan tanya } \\
\text { jawab }\end{array}$ & $\begin{array}{c}\text { Diberikan } \\
\text { melalui } \\
\text { pengajian } \\
\text { bersama- } \\
\text { sama }\end{array}$ & $\begin{array}{c}\text { Suka } \\
\text { memarkan } \\
\text { barang } \\
\text { kepada } \\
\text { orang lain }\end{array}$ & $\begin{array}{c}\text { Malu untuk } \\
\text { memamerkan } \\
\text { barang yang } \\
\text { dimiliki }\end{array}$ \\
\hline
\end{tabular}

\section{Kepribadian Santri}

"Kegiatan bimbingan mental Pondok Pesantren An-Najah Desa Tanjungrejo Kecamatan Jekulo Kabupaten Kudus diikuti penuh semangat oleh semua santri, sehingga ini akan memberikan dampak tersendiri bagi santri, seperti memiliki perilaku yang baik, memiliki kepribadaian Islam, seperti selalau mengikuti sholat 5 waktu berjama'ah, disiplin waktu dalam melakukan sholat berjama'ah, selalu shalat sunnah rawatib dan sholat dhuha dan sebagainya. dapat

\footnotetext{
${ }^{25}$ Wawancara dengan Ahmad Syukron Ustadz di Pondok Pesantren An-Najah di desa tanjungrejo Kecamatan jekulo kabupaten kudustanggal 20-11-2019 Pukul 11:00
} 
dipahami bahwa santri di Pondok Pesantren An-Najah Desa Tanjungrejo Kecamatan Jekulo Kabupaten Kudus memiliki kepribadian yang harus dimiliki dan dilakukan oleh santri yang ada di pondok tersebut, yaitu:

1. Selalu mengikuti sholat 5 waktu berjama'ah diwajibkan bagi santri untuk selalu shalat fardhu berjama'ah yang dilakukan di masjid.

2. Disiplin waktu dalam shalat berjama'ahSantri tidak diperkenankan untuk shalat sendiri saat di lingkungan Pondok Pesantren An-Najah Desa Tanjungrejo Kecamatan Jekulo Kabupaten Kudus harus mengikuti jadwal kegiatan shalat berjama'ah dengan tepat waktu.

3. Selalu sholat sunnah rawatib dan shalat dhuhaSantri diharuskan untuk shalat sunnah rawatib dan di anjurakn secara istiqomah dan bahkan untuk diwajibkan untuk shalat dhuha setip hari.

4. Santri selalu berakhlakul karimah dimana saja berada, guyub, rukun santri diharapkan memiliki rasa solidaritas dan toleransi antra santri di lingkungan pondok An-Najah Desa Tanjungrejo Kecamatan Jekulo Kabupaten Kudus dengan selalu menjaga kerukunan santri

5. Santri menjaga kebersihan

6. Santri diharuskan saat makan harus menjaga kebersihan, seperti membunag sampah pada tempatnya, membersihakn kamar secara jadwal, membersihkan pondok secara terjadwal dengan baik.

7. Yang terpenting lagi santri tiada waktu tanpa belajarSetiap hari santri harus menambah pengetahuan tentang agama Islam melalui mengkaji tafsir AlQur'an ataupun kitab kuning.Sehingga diharapkan santri benar-benar benar memiliki kepribadian Islam yang baik untuk selalu dijaga dan diajadikan dalam lingkungan pondok dan bahkan juga dijalankan di lingkungan masyarakat. ${ }^{26}$

Melihat adanya peranan yang dilakukan oleh para Ustadz dapat dilihat bahwa Ustadztelah melakukan kegiatan yang sesuai dengan objek (garapan) bimbingan mental yang berkaitan dengan hal-hal sebagai berikut:

1. Upaya-upaya mencegah dan mengatasi problem yang berkaitan dengan keberagamaan

2. Upaya-upaya mencegah dan mengatasi problem yang berkaitan dengan kesulitan dalam belajar membaca kitab kuning

3. Upaya-upaya mencegah dan mengatasi problem yang berkaitan dengan kekurang pahaman mengenai syariat Islam, seperti sholat, bersuci dan lain sebagainya

4. Upaya-upaya mencegah dan mengatasi problem yang berkaitan dengan ketidakmauan dan ketidakmampuan menjalankan syariat Islam dengan baik dan benar.

\footnotetext{
${ }^{26}$ Wawancara dengan Takwi Nasir Santri di Pondok Pesantren An-Najah di desa tanjungrejo Kecamatan jekulo kabupaten kudustanggal 20-11-2019 Pukul 15:00
} 
Sehingga sebagai seorang muslim dituntut berusaha sekuat tenaga mengatasi hidup dan segala persoalanya, memiliki iman yang kuat, tegar dalam bersikap dan tabah dalam menghadapi segala persoalan hidup. Bahagia hidup di dunia dan akhirat adalah salah satu tujuan hidup manusia dan semua itu akan tercapai jika manusia mau dan mampu beramal saleh dan berkhlak mulia. Maka dari itu, untuk membina dan membangkitkan mentalitas seorang perlu adanya bimbingan mental karena bimbingan mental merupakan bantuan pencerahan dan pembinaan jiwa, termasuk hati dan akal.

Dengan demikian, peran Ustadz dalam membimbing mental santri membentuk kepribadiaan Islam di pondok peantren An-Najah Tanjungrejo Jekulo Kudus dilakukan sedah baik, yaitu memberi dorongan dan bimbingan agar santri dapat mengaplikasikan materi mu'idhza hasanah dalam kehidupannya sehari-hari, seperti berbicara yang sopan dengan guru, bertemu dengan guru mengucapkan salam atau hormat, membantu orang tua di rumah, srtiap hari belajar tentang keagamaan Islam dan lain sebagainya. Dan memberikan contoh yang baik seperti melaksanakan shalat 5 waktu berjama'ah di masjid. Di samping itu mengajak santri untuk mengikuti kegiatan-kegiatan keagamaan,seperti memperingati hari-hari besar Islam, melaksanakan akhirussannah dengan baik, dan lain sebagainya.

\section{Penutup}

Ustad memiliki peran yang sangat penting dalam membimbing mental santri membentuk kepribadian Islam di Pondok Pesantren An-Najah Tanjungrejo Jekulo Kudus. Bimbingan tersebut dilakukan dengan memberikan arahan yang telah diajarkan oleh para ustadz. Ustaz juba berperanan memberi dorongan agar santri dapat mengaplikasikan dalam kehidupan sehari-hari yang telah diajarkan di pondok pesantren, baik pembelajaran tentang agama dan pembinaan jiwa, termasuk hati dan akal yang dilakukan oleh ustadz di pondok pesantren An-najah. Upaya membentuk akhlak santri Pondok Pesantren AnNajah diwujudkan dalam berbagai kegiatan. Dalam upaya menanamkan cinta kepada Allah dan Agar santri memiliki akhlak yang baik, maka di pesantren maupun di lingkungan. Hal ini lebih diorientasikan pada pembelajaraan agama yang nantinya akan dapat mempengaruhi kepribadian santri serta menimbulkan kecintaan kepada Allah. 


\section{Bibliografi}

Tim penyusun Diektorat Jendral Kelembagaan Agama Islam, Pola Pembelajaran Dipesantren, Departeman Agama RI, Jakarta, 2003.

Dewa Ketut Skardi, Proses Bimbingan Dan Penyuluhan, Ineka cipta, jakarta, 1998.

Faktor-faktor Penyebab Kenakalan Remaja di Desa Kemadang Kecamatan Tanjungsari Kabupaten GunungkidulSiti Fatimah dan M Towil Umuri,urnal Citizenship, Vol. 4 No. 1, Juli 2014

Syamsul Yusuf LN, Psikologi Praktis; Anak, Remaja dan Keluarga, BPK Gunung Mulia, Jakarta, 2004.

Prayitno dan Erman Amti, Dasar-Dasar Bimbingan Konseling, Rineka Cipta, Jakarta.1994.

Farida dan Saliyo, teknik layanan bimbingan Konseling Islam, STAIN kudus, Kudus, 2008.

Soeparwoto, dkk, Psikologi Perkembangan, UPT MKK UNNES Press, Semarang, 2003.

Zakiyah Daradjat, Ilmu Jiwa Agama, Bulan Bintang, Jakarta, 1970, hml.74.

http://animenekoi.blogspot.com/2016/06/jenis-jenis-bimbingan ,html, diakses tanggal 30 Desember 2016.

Abdullah, "Metode Dakwah Islam" Artikel, diambil melalui http:/dakwahislam.org/macam-macam-metode-dakwah.html, diakses tanggal 30 desember 2016.

Abdul Mujib, Kepribadian Dalam Psikologi Islam, Raja Grafindo Persada, Jakarta, 2006.

Al-Qur'an Surat Al-A'raf ayat 54, yayasan penyelangaraan penerjemahan dan penafsiran Al-Qur'an, Al-Qur'an dan Terjemahannya, Depag RI, Jakarta, 1991,hlm. 159.

Fathi Yakan, Seri Madah Tarbiayah Memotret Wajah Dakwah, Memetakan Problem Dan Menawarkan Solusi, PT Era Aicitra Intermedia, Solo, 2010 
80 Islamic Counseling: Jurnal Bimbingan dan Konseling Islam, Vol. 4, No. 1, 2020

Halaman sengaja dikosongkan

Halaman sengaja dikosongkan 